\title{
A framework for the urban eco-metabolism model - Linking metabolic processes to spatial patterns
}

\author{
Wen Liu ${ }^{\text {a, b }}$, Andrew C. Chang ${ }^{\text { }}$, Weiping Chen ${ }^{\text {b, }}{ }^{*}$, Weiqi Zhou ${ }^{\text {b }}$, Qi Feng ${ }^{\text {a }}$ \\ ${ }^{a}$ Key Laboratory of Ecohydrology of Inland River Basin, Cold and Arid Regions Environmental and Engineering Research Institute, Chinese Academy of \\ Sciences, Lanzhou 730000, China \\ b State Key Laboratory for Urban and Regional Ecology, Research Center for Eco-Environmental Sciences, Chinese Academy of Sciences, Beijing 100085, \\ China \\ ${ }^{c}$ Department of Environmental Sciences, University of California, Riverside, CA 92521, United States
}

\section{A R T I C L E I N F O}

\section{Article history:}

Received 25 October 2016

Received in revised form

5 July 2017

Accepted 7 July 2017

Available online 8 July 2017

\section{Keywords:}

Landscape patterns

Mass balance

Eco-metabolic processes

Materials and energy flows

Water metabolism

\begin{abstract}
A B S T R A C T
Rapid urbanization disordered the urban metabolism, pressed the contradiction between resources supply and demand, and caused urban environment deterioration. Urban metabolism provides important insights into the characterization of material and energy flows and the relationships between anthropogenic urban activities and natural processes. However, linking socio-economic and ecologic models, and tracking the time-dependent distribution and configuration of material and energy flows across the entire city are imperatively needed in urban metabolism model development. In this study, the points, lines and areas concepts were introduced to connect the urban landscape patterns and ecometabolic processes. A framework developed to simplify the urban landscape as areas, and use points and lines to depict the eco-metabolic processes in space. In application, a model framework of urban water metabolism was used as an example to analyze the natural hydrological processes and social water metabolism in an urban ecosystem. Water balance of a community was calculated by the model. The total input and output of the community's water metabolism was $50189.6 \mathrm{~m}^{3}$ and $47343.5 \mathrm{~m}^{3}$ respectively. The community needed $1331.4 \mathrm{~m}^{3} / \mathrm{d}$ water input and discharge $1198.26 \mathrm{~m}^{3} / \mathrm{d}$ wastewater out. The runoff coefficient of the impervious area, pervious area and the community was $0.87,0.30$ and 0.55 , respectively. The model has provided a tool for urban planners to improve landscape patterns and infrastructure layouts within urban ecosystem to build sustainable cities.
\end{abstract}

๑) 2017 Elsevier Ltd. All rights reserved.

\section{Introduction}

The world is undergoing rapid urbanization, and more than half of the population now lives in cities (UNFPA, 2007). This trend has significantly accelerated the energy, resources, pollutants, and wastes flowing into and/or out of the city boundaries (Kennedy et al., 2007). Urbanization impacts a city's metabolism in two respects. First, land uses and modifications of urban surfaces lead to smaller and more fragmented patches of "natural" habitats (Hahs et al., 2009; Savard et al., 2000), resulting in interruptions of ecosystem services and influencing the dynamics of the materials and energy flows (Alberti et al., 2008). Second, demands for raw materials and energy are accelerated to sustain the population

\footnotetext{
* Corresponding author.

E-mail address: wpchen@rcees.ac.cn (W. Chen).
}

growth and rapid urbanization (Kalmykova et al., 2015). As a result, the conflicts between supply and demand for resources, risks of pollutant accumulation, and waste discharge may be seriously aggravated (Baud et al., 2001; Varis and Vakkilainen, 2001). It caused deterioration of air and water quality, increases in greenhouse gases emissions and accumulation of solid wastes (Compton et al., 2011; Kalnay and Cai, 2003). The fundamental reason for these problems is a disorder of the urban metabolism (Brunner, 2007; Kennedy et al., 2010). Urban planners have faced the challenge of designing the metabolism of sustainable cities to minimize material throughput by integrating efficient buildings and urban infrastructure with spatial planning (Holmes and Pincetl, 2012; Kennedy et al., 2011; Rees, 1999).

In practice, urban metabolism serves as a model of a system that combines anthropic activities occurring in cities and their related urban infrastructure (Beloin-Saint-Pierre et al., 2016). Urban metabolism research provides important insights into the 
characterization of material and energy flows and the relationships between anthropogenic urban activities and natural processes and cycles (Decker et al., 2000; Kennedy et al., 2007). Research on urban metabolism focuses on the sources and consumptions of resources, and on their circulation within the urban ecosystem (Zhang, 2013). Wolman (1965) and many other scholars have analyzed the resource input and output flows of cities and urban communities in terms of ecological metabolism (Barles, 2009; Hendriks et al., 2000; Ngo and Pataki, 2008; Warren-Rhodes and Koenig, 2001). Some researchers analyzed the material and energy flows in industries, households and megacities, and the resulting environmental impacts assessments (Kennedy et al., 2014; Lei et al., 2016; Liu et al., 2011; Sahely et al., 2003; Zhang et al., 2006). Other researches have attempted to make metabolic studies spatially explicit by considering the interactions between urban metabolism and the spatial distribution of land use and cover types (Huang and Chen, 2009; Lee et al., 2009; Marull et al., 2010; Lu et al., 2016).

Material flow analysis (MFA), life cycle assessment (LCA), ecological network analysis, emergy analysis and ecological footprint are common approaches and models to quantify the flows of material and energy through complex systems (Barles, 2007; Zhang, 2013). MFA measuring the inflows and outflows of a city's materials is an effective way to support the resource and environmental management. Few approaches have developed indicators related with spatial or distance information to analyze MFA towards policy management strategies and urban planning (Kennedy et al., 2014; Inostroza, 2014; Leduc and Van Kann, 2013; Vivanco et al., 2012). LCA offers a practical suite of methodologies and tools for quantifying the materials of an urban metabolism, including the processes generating inputs and outputs (Pincetl et al., 2012). The fusing of urban metabolism and LCA has been used to assess urban sustainability and quantify environmental impacts of cities (Chester et al., 2012; Goldstein et al., 2013; Sun et al., 2016). Ecological network and emergy analysis are increasingly being adopted to simulate the structure and function of urban metabolic system (Zhang et al., 2009, 2010; Li et al., 2012). In addition, the ecological footprint is popularly used as an acclaimed tool for measuring and visualizing the resources required to sustain urban ecosystem (Dakhia and Berezowska-Azzag, 2010; Kenny and Gray, 2009; Novotny, 2010), and it can help to reflect the complementary relationship between natural capital and socioeconomic development. To simplify the complex relationships of a predefined socio-economic system, MFA omits many outflows and interactions within and between the natural and man-made segments of the urban systems (Huang et al., 2006), and lacks a unified methodology (Rosado et al., 2014). LCA still requires greater spatial and temporal resolution, large quantities of data, improved non-linear modeling capabilities, and greater consideration of the socioeconomic dimensions of urban environmental impacts (Haes et al., 2004). For the ecological network analysis, the lack of flows among networks in a socioeconomic system makes it difficult to refine the sectors of the network, and the ecological connotation of simulating the network structure requires additional analysis (Zhang, 2013). In emergy analysis, the confusion lies in definition, quantification and location, and there is a need to link emergy to other thermodynamic concepts and other related techniques (Hau and Bakshi, 2004). Ecological footprint analysis has been weaker on providing actual space-related solutions that city managers can use in their daily work (Chrysoulakis et al., 2013; Yang et al., 2014).

Urban metabolism is valuable in quantifying the consumption of natural resources but does not achieve a comprehensive analysis of the urban ecosystem (Holmes and Pincetl, 2012; Golubiewski, 2012; Tischendorf, 2001). An urban metabolism model that includes the spatial framework linking the urban landscape patterns and urban metabolism processes is able to assess how landscape patterns impact urban metabolism processes (Minx et al., 2011; Zhang, 2013). In model development, it is vital to link socioeconomic and ecologic models and track the time-dependent distribution and configuration of material and energy flows across the entire city (Bennett and Saunders, 2010; Cadenasso et al., 2007; Irwin and Bockstael, 2007).

In this research, the points, lines and areas concepts were introduced to connect the urban landscape patterns and ecometabolic processes together, and to couple natural circulation and socio-economic activities with urban ecosystems. A framework for the urban water metabolism model was developed to track and account for water inputs, outputs, and stocks in an urban ecosystem. As an example, the resulting model framework was used to analyze the natural and social water metabolic processes and water balance of a community in Beijing. The model framework helps urban planners and decision makers to effectively assess and regulate the landscape patterns, infrastructure layouts, resource consumption, pollution distribution and waste discharges to build sustainable cities.

\section{Urban eco-metabolism model framework development}

To track the configuration of material and energy flows across the entire urban ecosystem, we introduce the "points", "lines" and "areas" concepts and develop an urban eco-metabolism model framework to link urban eco-metabolic processes taking place temporally and spatially across the urban landscape. The technology flow chart of the model framework is shown in Fig. 1.

\subsection{Landscape patterns simplification}

An urban ecosystem consists of a series of interrelated yet fragmented natural and man-made landforms, each going through its distinctive metabolic processes that take place simultaneously and perform defined urban ecological functions (Godron and Forman, 1983). Urban landscape is a complex mosaic of interconnected patches of natural and man-made segments having varying metabolic attributes (Machlis et al., 1997). As a simplification of the intricate urban landscape patterns, the natural landforms are distinguished from the background of man-made landforms as patches, that is viewed the natural landforms embedded in the whole man-made system. The patches are the non-overlapping blocks divided by major thoroughfares and mosaic natural patches of urban space, and will be spatially linked by employing the eco-metabolic processes. The man-made landforms are constructed landscapes including buildings, roads and paved surfaces that constitute the backbone of urban ecosystems. The natural landforms are relatively homogeneous patches of green spaces, lawns, forests, wetlands, and water bodies of varying sizes and shapes. Therefore, urban landscape patterns are depicted as huge numbers of rectangular or irregular blocks that are divided by major thoroughfares, and the natural patches inlaid in these blocks (Fig. 2).

\subsection{The mass balance and routes of eco-metabolic processes analysis}

The city, as an ecosystem, is highly dependent on large inputs of energy and materials and has a vast capacity to metabolize and consume resources and energy inputs and generate emissions and waste (Collins et al., 2000; Grimm et al., 2008; Kaye et al., 2006; Marcotullio and Boyle, 2003). According to Churkina (2008), the boundary of an urban ecosystem was defined as the area required to meet the demands of the urban population in terms of consumption and waste accumulation. To illustrate the relationships, 


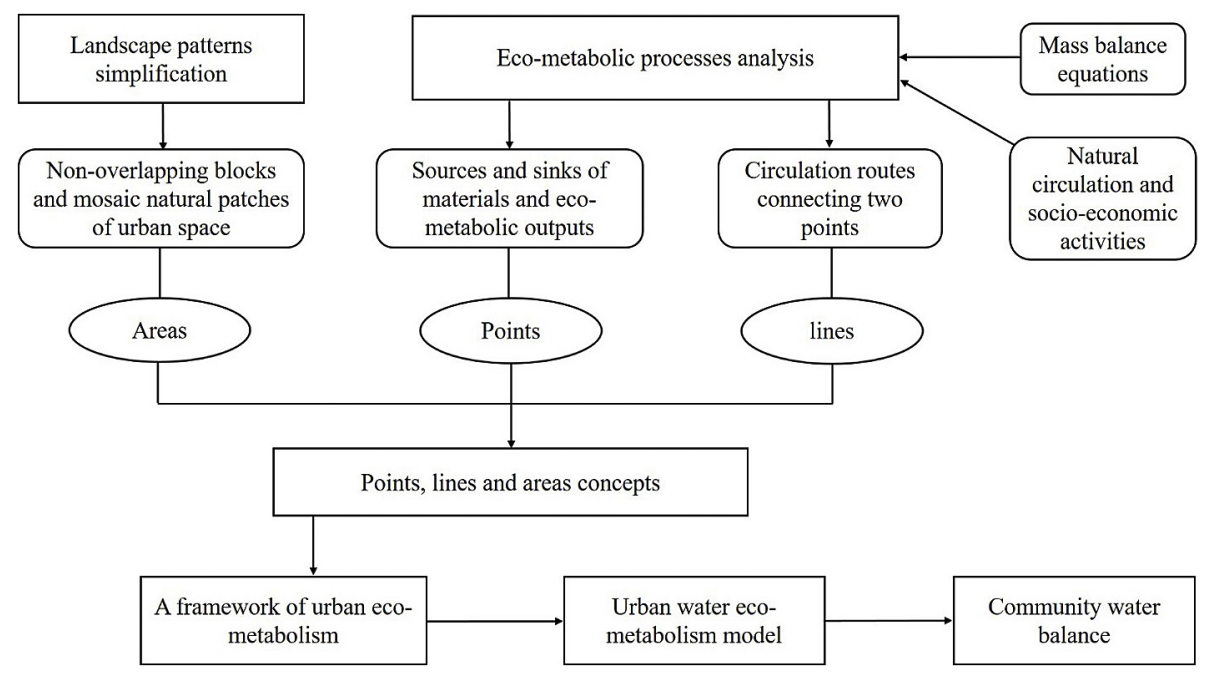

Fig. 1. Flow chart of the model framework.

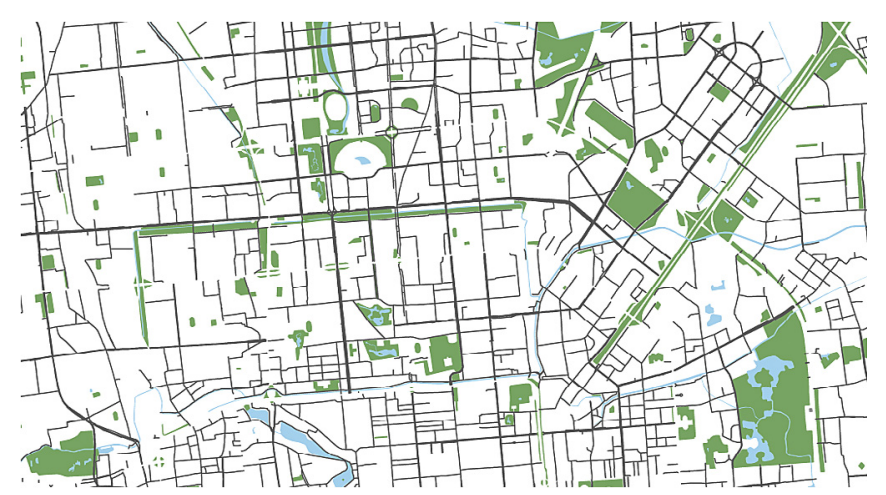

Fig. 2. A diagram of simplified urban landscape patterns. It is a part of land use and land cover map in Beijing, it depicts the natural patches (green and blue parts) inlayed in huge number of blocks (white parts) which divided by major thoroughfares (grey lines). (For interpretation of the references to colour in this figure legend, the reader is referred to the web version of this article.)

the following framework focuses primarily on the eco-metabolic processes applicable to water, carbon, food, energy, and pollutant flows in an urban ecosystem. The mass equilibrium equation for material or energy transformation in a system was established based on the mass balance principle. The change of material or energy storage of an urban ecosystem over time, $\Delta S$, is equal to the total inputs $Q_{i}$ minus the total outputs $Q_{0}$ over the time period (Fig. 3).

$\Delta S=Q_{i}-Q_{0}$

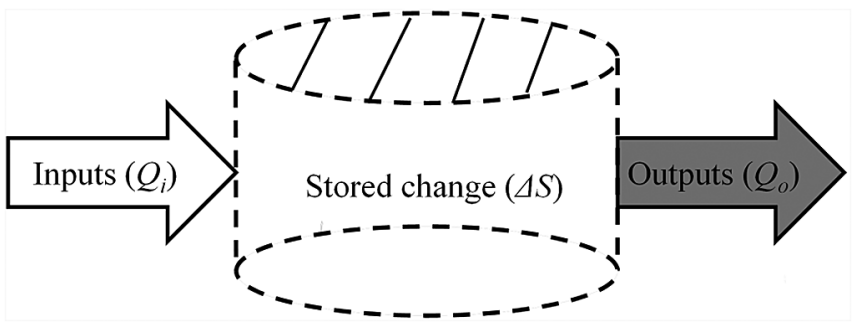

Fig. 3. Schematic depiction of urban ecosystem mass balance. Source: (Kenway et al., 2011).
Within the urban ecosystem, the metabolism of each patch follows a pathway of cycles, nodes and routes, which encompass a part or the entire metabolism processes. For example, the ecometabolic pathways of material or energy in a subsystem $W$, are hypothesized to consist of two routes (Fig. 4), $L$ and $M$, that have $n$ and $\mathrm{m}$ nodes respectively (i.e. the functional infrastructures of social metabolism and import/export sites of W, such as water supply plants, power plants, packinghouses, markets, settlements, wastewater outlets and waste yards) with corresponding intermediates $S_{1}, S_{2}, \ldots S_{\mathrm{n}}$ and $K_{1}, K_{2}, \ldots K_{\mathrm{m}}$ for routes $L$ and $M$, respectively.

The input materials and energy, $I_{\mathrm{L}}$, enter eco-metabolic route $L$ of $W$, flow through nodes 1 to $n$ resulting in intermediates, $S_{1}, S_{2}, \ldots$ $S_{\mathrm{n}}$, that lead to the outputs of the $W$. At any node $i$ intermediate $S_{\mathrm{i}}$ is transferred to $S_{\mathrm{i}+1}$ according to reaction function $S_{\mathrm{i}+1}=f_{\mathrm{i}}\left(S_{\mathrm{i}}\right)$. For route $M$, the derivations are the same. Between two routes (i.e. $L$ and $M$ ) there exist mechanisms through which portions of intermediates may transfer back and forth by way of exchange functions $Q_{\mathrm{i}}=k \times\left(K_{\mathrm{j}}-S_{\mathrm{j}}\right)$, where $k$ is the diffusion coefficient of materials and energy. In this way each participates in the ecometabolic processes of the other's route, thus linking the ecometabolic pathways of materials and energy. For quantifying the eco-metabolic processes of flows, the mathematical functions based on natural cycle mechanisms, as well as social consumption and discharge are used to describe the material and energy metabolism processes. Then, the mass balance equations are employed to calculate the storage change and output flow of areas and nodes within the urban ecosystem.

\subsection{Points, lines and areas concepts}

"Points" are defined as the sources and sinks of materials,

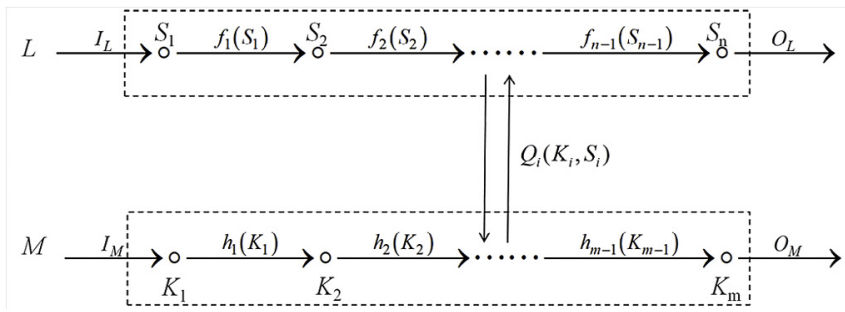

Fig. 4. Schematic routes of eco-metabolic processes. 
energy, and eco-metabolic outputs. "Lines" are circulation routes connecting two points through which materials and energy are transported across boundaries for distribution and/or further reactions. The "lines" are characterized in terms of substances, capacities, flow velocity and direction of eco-metabolic processes. "Areas" are the non-overlapping blocks divided by major thoroughfares and mosaic natural patches of urban space. For specific materials and energy flows, the "areas" should be detailedly partitioned according to its unique eco-metabolic attributes. Each "area" has both natural and social metabolic processes and contained social nodes or pathway across it. At the interface of two "areas", eco-metabolites in the form of materials and energy may undergo cross boundary exchanges and then redistribution, or may cross the border by participating in any reaction via the "lines".

Using the "points" and "lines" of material and energy flows in the urban ecosystem, it becomes possible to identify the key nodes of eco-metabolic processes, as well as the paths between these nodes and the interacted fluxes between the numerous natural "areas". In application, the model should firstly identify and positioning the concrete "points" and "lines" on the urban space according to the block diagrams of metabolic processes using considerable information such as infrastructures distribution and resources conveying, and created the eco-metabolic networks on the urban space. And then overlay census data as well as the socioeconomic activities and natural circulation that are metabolizing the inputs, stocks and generating the outputs within each "area".

\section{Urban water eco-metabolism model development and example implication}

\subsection{Urban water eco-metabolism model development}

Water is an essential resource of an urban ecosystem (Decker et al., 2000; Wolman, 1965). Urbanization has resulted in changes of landforms that radically alter the paths and volumes of water flows into, within, and out of urban areas (Bonan, 2002). Increasingly, the urban areas around the world are facing pluvial flooding and water scarcity, often at the same time, due to the uncertainties of climate change (Chen et al., 2010; Vairavamoorthy et al., 2008). The flows and balances of water mass through an urban metropolis would be a fitting start to articulate the metabolic processes of the urban ecosystem (Heaney et al., 2000).

\subsubsection{Landscape pattern partition}

The complex urban land forms may be partitioned into blocks of homogeneous water metabolic attributes by interpreting remote sensing images. The points and lines that define how urban water flows and converts through the landscape, then may be laid on top of the sectioned urban areas. For routing the precipitation and overland flows, urban land areas may be divided according to water permeability into: impervious (mostly man-made areas), pervious (mostly natural areas), and water bodies (a subset of natural areas). Each category has its unique eco-metabolic processes to accommodate water. The precipitation and overland flows of the impervious surfaces such as roofs of buildings, roads, pavements, and parking lots may not be accommodated in situ and points and lines are needed to be in place to collect and discharge the water. Precipitation and overland flows entering the pervious areas, including greenbelts, lawns, forests and bare lands, may permeate and be stored in the soil, and only the excess water needs to be routed. The water stored in the soil will then flow through the terrestrial water cycle. The water bodies including lakes, rivers, reservoirs, wetlands, and artificial waterscapes are devices where water may be temporarily or permanently stored. In addition, the public water supply internally produced and/or imported will leave the treatment plants (points) and be distributed (via lines) for consumption in the areas. The eco-metabolic processes of water may then be converted into a flow diagram and defined in quantitative terms.

\subsubsection{Conceptual diagram of urban water flows}

The conceptual flow chart for urban water includes pathways for natural and man-made settings. The water of the natural settings undergoes precipitation, interception, evaporation, infiltration and runoff processes that include horizontal and vertical fluxes and mass exchanges at interfaces with the atmosphere and soil. The repositories of the natural water cycle are atmospheric, surface, and ground water bodies. The social water cycle depicts water movements in the man-made areas that consist of public water supply and distribution networks, and the wastewater collection, treatment, and disposal system. Together, the urban water cycle is outlined in the following conceptual flow chart (Fig. 5):

Accordingly, the points and lines of urban water cycle may be clearly recognized and delineated.

\subsubsection{Developing urban water eco-metabolic functions}

The quantities and velocities of water being transferred between points through the lines may be represented by mathematical functions defined by the hydrological processes, water consumption patterns, and wastewater generation and treatment ratio. To balance the water mass computation algorithms route the water area by area and integrate over the entire city. The water balance of the unit model was adopted and modified the water balance equation described by Mitchell et al. (2003) and Kenway et al. (2011) as shown:

$\Delta S=(P+I)-(E T+G+R S+D W+L)$

where $P$ is precipitation; $I$ is water supplies for industrial, commercial, residential and irrigative uses, and includes centralized water such as major surface and groundwater sources, decentralized water from groundwater and rainwater cisterns, and imported water; $E T$ is the actual evaporation and includes depression water in impervious areas and pervious areas, water intercepted by vegetation and soil water evaporation; $G$ is water infiltration into groundwater; $R S$ is stormwater runoff; $D W$ is wastewater discharge; $L$ is water vaporized into the atmosphere by anthropogenic activities, which includes water loss in production or water consumption. $P$ and $I$ are the inputs and $E T, G, R S, D W$, and $L$ are outputs of the urban water system. $\Delta S$ is the change in stored water volume. Stored water $S$ includes soil moisture, water in pipes, rainwater cisterns and urban water bodies. The reuse water is mostly used for irrigation and the leakage of water supply and wastewater collection pipes also flows into the soil, these could be considered an output (i.e., part of $G$ ). Additionally, the aqueous foods, drinks and bottled water imported from outside were minimal (Wolman, 1965), and were ignored in this example.

The water eco-metabolic functional nodes and water pathways are delineated in Fig. 6. The water mass balance equations of the eco-metabolic functional nodes are listed in Table 1 . The water consumption of different social functional districts was estimated based on water consumption norms. $P$ was obtained from meteorological data. Finally, the input, storage and output of each area were acquired. Therefore, the eco-metabolic functional nodes, flow paths and distribution of water were mapped on the urban space using GIS technology. At the large scale, the total supplied water, storage amount, rainwater and wastewater discharge of the whole city were the sum of all areas respectively. Due to the complexity of urban space and experimental data availability, the unit model can build on the community scale first and adjust the model with 


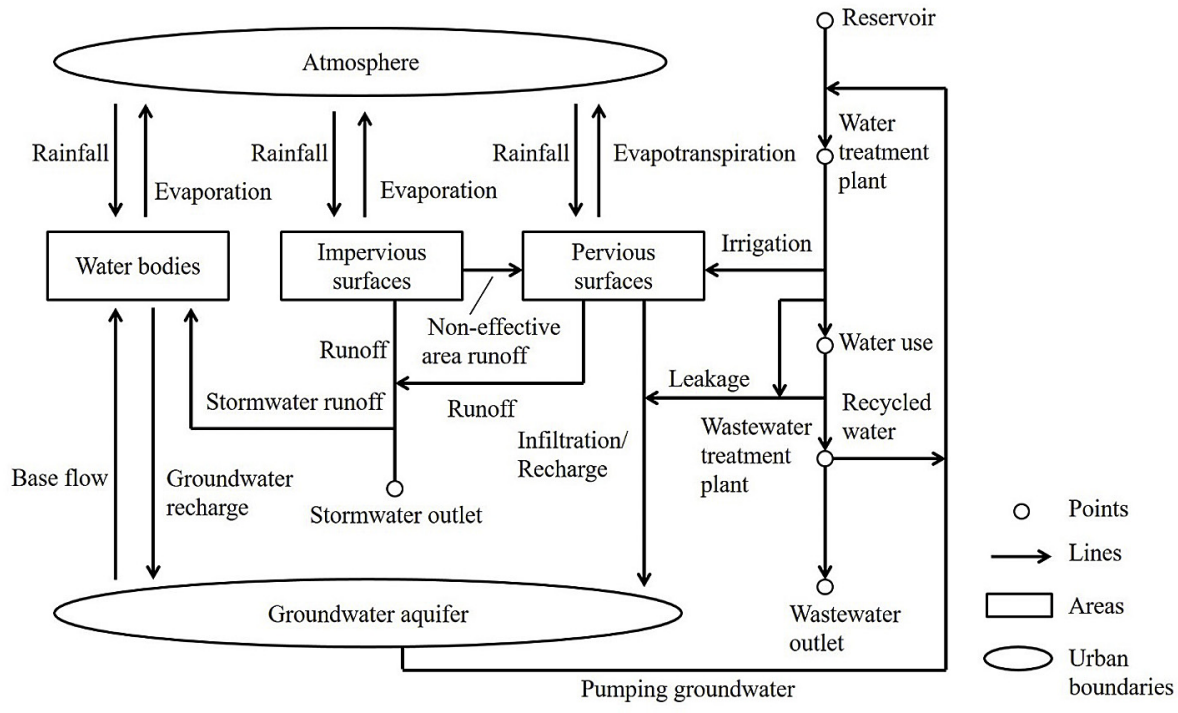

Fig. 5. Conceptual points, lines and areas of urban water eco-metabolism.

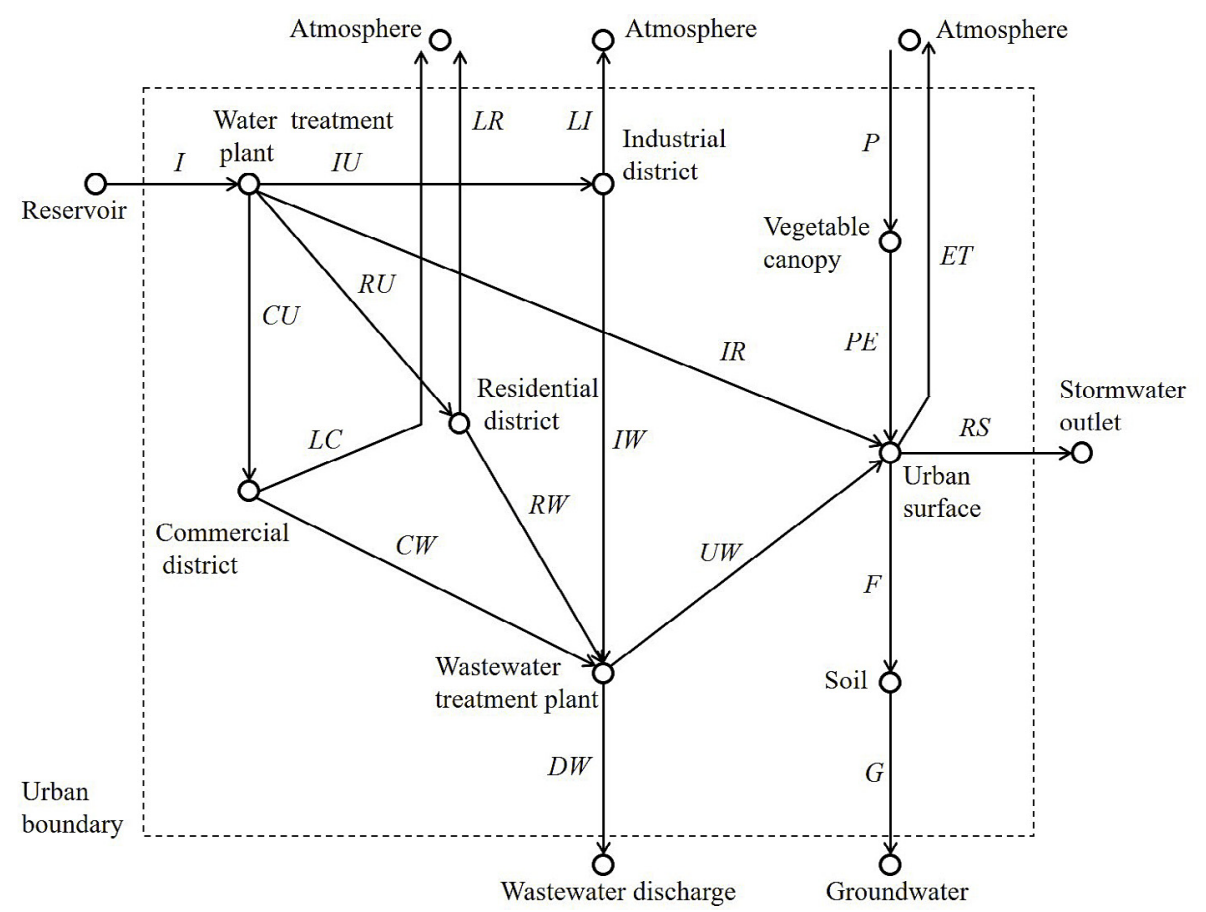

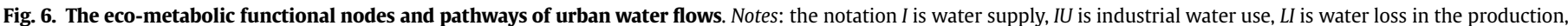

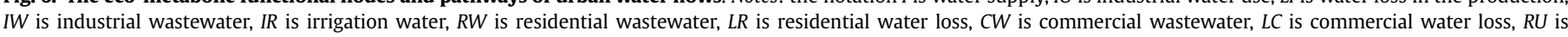

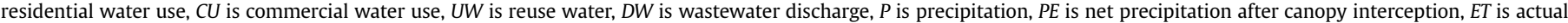
evaporation, $R S$ is stormwater runoff, $F$ is rainwater infiltration, and $G$ is recharge groundwater.

experimental data and social information, and then expand to the urban scale.

\subsection{Example implication}

\subsubsection{A case study of community's water balance}

We used the equations in Table 1 to calculate the monthly water balance of the Wangchunyuan community $\left(40^{\circ} 02^{\prime} 36^{\prime \prime} \mathrm{N}\right.$, $116^{\circ} 24^{\prime} 54^{\prime \prime}$ E, Chaoyang District, Beijing) in August 2012. The community has 13 high-rise residential buildings with 9510 residents. The high-resolution remote sensing image of positive landform of the study area was obtained by Google Earth software (data source: QuickBird, spatial resolution: $0.61 \mathrm{~m}$ ), and then the land cover types obtained by visual interpretation (shown in Fig. 7). The total area of the study area was 13.0 ha. The area of pervious surfaces occupied the largest area of 5.51 ha $(42.38 \%)$, followed by the impervious surfaces occupied the area of 5.22 ha, others were the water bodies ( $2.27 \mathrm{ha}$ ).

According to the above framework and analysis, the points, lines and areas of the community's water metabolism were defined and mapped on Fig. 7. The points denoted the outlets of stormwater drainage, the inlets of water supply, and the outlets of wastewater 
Table 1

Water mass balance equations for water eco-metabolic processes.

\begin{tabular}{|c|c|}
\hline Water flows & Water balance equations ${ }^{a}$ \\
\hline Water supply & $I=R U+C U+I U+I R$ \\
\hline Industrial water use & $I U=i p \times u i$ \\
\hline Water loss in the production & $L I=\mu \times I U$ \\
\hline Industrial wastewater & $I W=I U \times(1-\mu)$ \\
\hline Irrigation water & $I R=v i \times v p$ \\
\hline Residential water use & $R U=r p \times u r$ \\
\hline Residential wastewater & $R W=\beta \times R U$ \\
\hline Residential water loss & $L R=R U-R W$ \\
\hline Commercial water use & $C U=p t \times u c$ \\
\hline Commercial wastewater & $C W=\alpha \times C U$ \\
\hline Commercial water loss & $L C=C U-C W$ \\
\hline Wastewater discharge & $D W=I W+R W+C W-U W$ \\
\hline Net precipitation after interception & $P E=P-S_{\mathrm{L}} \times L A I$ \\
\hline Stormwater runoff & $R S= \begin{cases}P E-E T-F-S d_{\max }, & \text { where pervious areas } \\
P-E T-D, & \text { where impervious areas }\end{cases}$ \\
\hline Actual evaporation & $E T=\min \left(0.0023 \times\left(R A_{\max } / \lambda\right)\left(T_{\max }-T_{\min }\right)^{0.5}\left(T_{\mathrm{av}}+17.8\right), S d_{\max }\right.$ or $\left.D\right)$ \\
\hline Rainwater infiltration & $F=K_{\mathrm{s}} t+S_{\mathrm{f}} \Delta \theta \ln \left(1+\mathrm{F} /\left(S_{\mathrm{f}} \Delta \theta\right)\right)$ \\
\hline Recharge groundwater & $G=\xi \times\left(\theta_{\mathrm{i}}+F+U W+I R-E_{\mathrm{s}}\right)$ \\
\hline
\end{tabular}

${ }^{a}$ Notations of equation parameters are defined as follows: ip, industrial production; $u i$, water consumption for per unit of industrial production; $\mu$, water loss coefficient of production; $v i$, irrigation area; $v p$, per unit of irrigation water; $r p$, residential population; ur, water consumption per capita; $\beta$, wastewater generation ratio in residential districts; $\alpha$, wastewater generation ratio in commercial districts; $S_{L}$, specific leaf storage; $L A I$, canopy leaf area index; $S d_{\text {max }}$, depression storage of pervious areas; $D$, initial loss of impervious areas; $R A_{\max }$, the extraterrestrial radiation of the surface related with latitude; $\lambda$, the latent heat of vapor; $T_{\max }$, maximum daily temperature; $T_{\min }$, minimum daily temperature; $T_{\mathrm{av}}$, average daily temperature; $K_{\mathrm{s}}$, saturated hydraulic conductivity; $S_{f}$, wetting front suction; $F$, accumulated infiltration; $\Delta \theta$, soil water deficit, which equals to the saturated water content $\left(\theta_{\mathrm{s}}\right)$ minus the initial water content $\left(\theta_{\mathrm{i}}\right)$; $t$, time interval; $\xi$, recharge coefficient; $E_{\mathrm{s}}$, soil water evaporation.

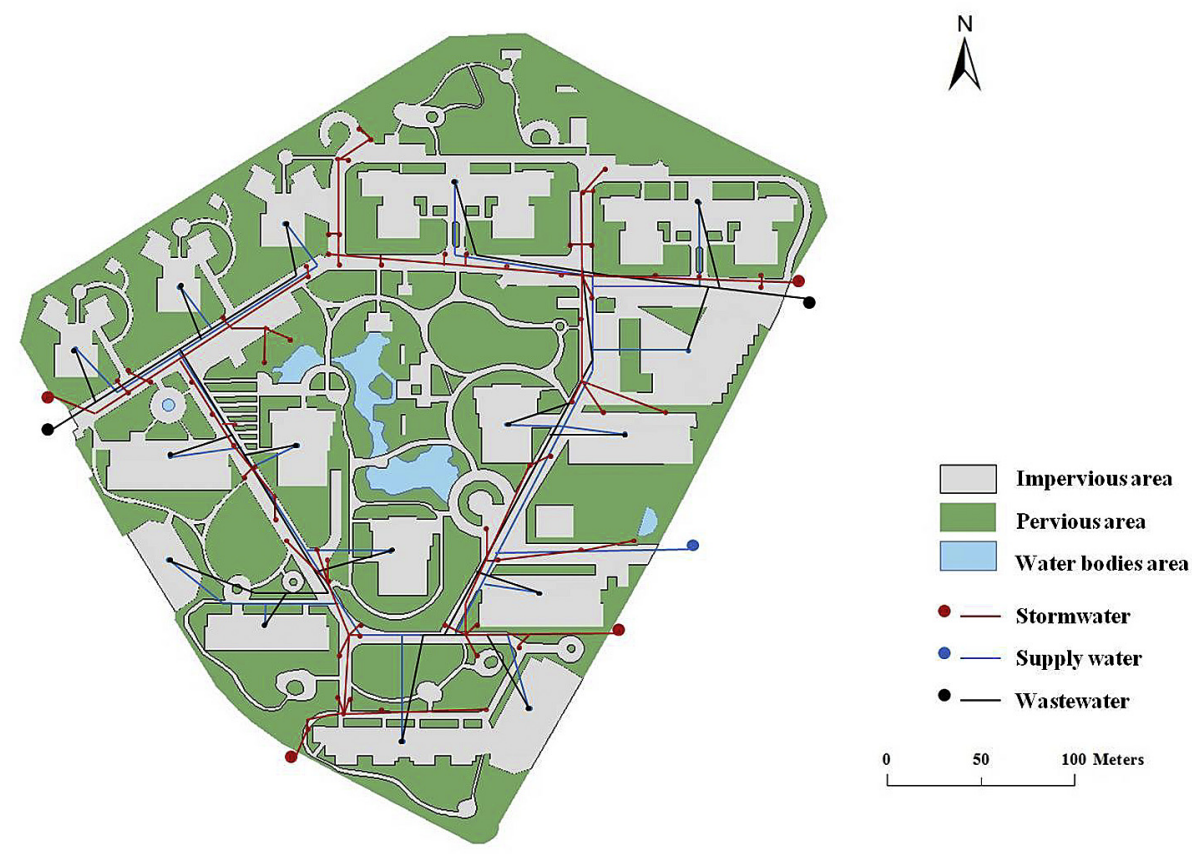

Fig. 7. The points, lines and areas of water eco-metabolism in the community.

discharge. The lines contained the pipes system of stormwater drainage, water supply and wastewater discharge. The areas divided into impervious surfaces include rooftops, cement surfaces, pavements and asphalt road; pervious surfaces include lawns and tree canopy; water bodies include ponds and artificial fountains. Due to the community as a residential sector, it does not include the whole function nodes of an urban ecosystem.

The rainfall and temperature data in August 2012 were acquired from the local meteorological department. Table 2 summarizes the parameter values used for water balance calculation of the community and their sources. The model assumed no irrigation or reused water during this period. The monthly water balance of the community is shown in Table 3.

The input of the community water metabolism contains social water supply and natural rainfall, which was $50189.6 \mathrm{~m}^{3}$. The output of the community water metabolism includes actual evaporation, water infiltration into groundwater, stormwater runoff, wastewater discharge and water loss in consumption, which was $47343.5 \mathrm{~m}^{3}$. Accordingly, water storage change of the community was $2846.1 \mathrm{~m}^{3}$. For the social water metabolism, the community needed $1331.4 \mathrm{~m}^{3} / \mathrm{d}$ water input to maintain 9510 residents' living demands. The wastewater discharge of the community was 1198.26 
Table 2

Parameters values used for water balance calculation of the community.

\begin{tabular}{|c|c|c|c|c|}
\hline Parameters & Notations & Values & Units & References \\
\hline Latent heat of vapor & $\lambda$ & 2.45 & $\mathrm{MJ} / \mathrm{kg}$ & Allen et al. (1998) \\
\hline Saturated hydraulic conductivity & $K_{\mathrm{s}}$ & 0.144 & $\mathrm{~mm} / \mathrm{min}$ & Xie et al. (1998) \\
\hline Wetting front suction & $S_{\mathrm{f}}$ & 69.696 & $\mathrm{~mm}$ & Fu et al. (2002) \\
\hline Saturated water content & $\theta_{\mathrm{s}}$ & 40.627 & $\%$ & Xie et al. (1998) \\
\hline Initial water content & $\theta_{\mathrm{i}}$ & 26.279 & $\%$ & Xie et al. (1998) \\
\hline Leaf area index & $L A I$ & 3.85 & - & Su and Xie (2003) \\
\hline Extinction coefficient & $\kappa$ & 0.3 & - & Wang et al. (2008) \\
\hline Special leaf storage & $S_{\mathrm{L}}$ & 0.2 & $\mathrm{~mm}$ & Wang et al. (2008) \\
\hline Initial loss of impervious areas & $D$ & 3 & $\mathrm{~mm}$ & Xu (1998) \\
\hline Depression storage of pervious areas & $S d_{\max }$ & 4 & $\mathrm{~mm}$ & Lei et al. (2010) \\
\hline Groundwater recharge coefficient & $\xi$ & 0.1852 & - & Tan et al. (2013) \\
\hline Water consumption per capita & $u r$ & 140 & $\mathrm{~L} / \mathrm{d}$ & Construction Ministry of China (2002) \\
\hline Wastewater generation ratio & $\beta$ & 0.9 & - & Tchobanoglous et al. (2003) \\
\hline
\end{tabular}

Table 3

The monthly water balance of the community.

\begin{tabular}{|c|c|c|c|c|c|c|c|c|}
\hline Composition $^{\mathrm{a}}$ & $P$ & $I$ & $E T$ & $G$ & $R S$ & $D W$ & $L$ & $\Delta S$ \\
\hline Volume $\left(\mathrm{m}^{3}\right)$ & 8916.20 & 41273.40 & 523.32 & 647.02 & 4899.76 & 37146.06 & 4127.34 & 2846.10 \\
\hline
\end{tabular}

$\mathrm{m}^{3} / \mathrm{d}$. For the natural water circulation (hydrological processes), more than half $(54.95 \%)$ of the rainfall as stormwater runoff discharged out the community. For the impervious surface, $86.92 \%$ of the rainfall reached ground was transferred into stormwater runoff. The pervious area has a low runoff coefficient of 0.30 . The actual evaporation and water infiltration into groundwater account for $5.87 \%$ and $7.26 \%$ of the rainfall respectively. The runoff coefficient of the community calculated by the model was close to other researches in China. Such as, based on the long term rainfall data and large-scale topographic map data, the average runoff coefficient of Nanjing urban area was calculated as 0.66 (Zhang et al., 2012). According to the "Code for design of outdoor wastewater engineering" (GB 50014-2006) and the proportion of pervious and impervious area, the calculated empirical runoff coefficient was 0.59 (Mohurd, 2011).

With the issue of sustainability at the core of many environmental issues today, one of the main uses of urban metabolism in the modern era is to track and record levels of sustainability in an urban ecosystem. The total input, output and storage states of urban water eco-metabolism can use to derive indicators to illustrate the content and significance of various natural and anthropogenic water flows as well as the degree of system centralization (Kenway et al., 2011). These indicators mainly include water use density, water system centralization, overall balance of inputs and outputs, stormwater potential for water supply, wastewater potential for water supply, and water cycle rate. These indicators would help urban planners quantify the hydrological efficiency and watersensitivity of cities, and analyze the urban design and water management impact on water sustainability.

The hydrology in urban areas can be further modified by ecological structures (Pickett et al., 2001). Among the most important modifications that affect the urban water balance is the increase in the impervious area (Elvidge et al., 2007; Grimm et al., 2008). The changes of underlying surface condition significantly alter the natural water cycle, and water infrastructure layout has influenced the utilization efficiency of water resources for a long time. Therefore, research on the impacts of land cover changes and infrastructures layout on soil water storage, stormwater runoff discharge and water utilization efficiency would be useful to optimize urban water management. Additionally, as the lines of water eco-metabolism indicate the exchange flows among areas, they can be used to evaluate the water ecological service of natural paths; for example, to evaluate the functions and services of green areas, forests and wetlands in terms of stormwater runoff decrease, groundwater recharge and water supply sources.

\subsubsection{The advantages of the model framework}

Compared with the MFA, LCA and other urban metabolism approaches, this framework is a process-based and dynamic model which linked ecological circulation processes and the underlying socio-economic activities to the complex urban landscape pattern. The model could temporally and spatially account for inputs, outputs, and stocks of materials and energy flows in the specific area. As the urban ecosystem dynamically changes, the model would adjust accordingly and rebalance the mass distributions across the urban landscape and over time. It can examine the interior mechanisms of the urban metabolism on urban space and reveal sufficient details of the exchanges of materials and energy fluxes among natural and man-made landforms. Moreover, it allows managers to increase channels within the metabolic network to decrease obstacles that impedes eco-metabolic processes, and link natural patches through increasing or decreasing in the number of paths connected to a node and changing the direction of fluxes along the paths within the overall metabolism network. It could help us to identify the capacity/function of the key infrastructures of ecometabolic processes and optimize the design and layouts of functional infrastructures and routes on the urban space to improve the metabolic efficiency. Thus, it can be beneficial to optimal regulation of an urban eco-metabolic system to increase metabolic efficiency. Therefore, this approach coordinated the planning of spatial development and infrastructure to better integrate urban form and flows, which provides relatively feasible and easier solutions for resources and waste management in cities than other approaches.

\section{Summary}

This framework utilized the points, lines and areas concepts and coupled natural circulation and socio-economic activities with urban ecosystems to spatially analyze the material and energy flow eco-metabolism within urban ecosystems. A model framework of 
urban water metabolism was used as an example to analyze the eco-metabolic processes in an urban ecosystem. Mass balance equations were used to calculate the inputs, storages and outputs of eco-metabolic processes to quantify and track the material and energy flows in urban space. Thus, the resulting model framework is used to analyze the natural and social water metabolic processes and water balance of the community. The total input and output of the community's water metabolism was $50189.6 \mathrm{~m}^{3}$ and 47343.5 $\mathrm{m}^{3}$ respectively. The community needed $1331.4 \mathrm{~m}^{3} / \mathrm{d}$ water input and discharged $1198.26 \mathrm{~m}^{3} / \mathrm{d}$ wastewater. The runoff coefficient of the impervious area, pervious area and the community was 0.87 , 0.30 and 0.55 , respectively.

In application, this approach can effectively quantify and evaluate the effects of landscape pattern changes, and infrastructure arrangement optimization on the urban water eco-metabolism, and provide decision support for landscape and infrastructure planning and water resource management. Our framework model is limited due to the large amounts of data for metabolic processes analysis of the entire urban ecosystem are often unavailable or of questionable quality in China. Only one urban metabolic aspect, water metabolism has been considered and analyzed in this study. This kind of systematic analysis is suggested with the inclusion of other carbon, food, energy and pollution metabolisms over the whole city. The differences of materials metabolic mechanism and urban form diversity would also need to be considered in the future work. Future work will be needed to provide detail about exchange effects among areas, and the cross impacts of different materials and energy flows. Through comprehensive analysis, this overall research could support urban planners and managers in optimizing resource utilization and pollution discharges in the entire city to achieve sustainable development in the future.

\section{Acknowledgements}

This study was supported by the National Natural Science Foundation of China (41601040), the CAS "Light of West China" Program (29Y729841), and the China Postdoctoral Science Foundation (2016M602899). We greatly appreciate suggestions from three anonymous referees for the improvement of our paper. Thanks also to the editorial staff.

\section{References}

Alberti, M., Marzluff, J.M., Shulenberger, E., Bradley, G., Ryan, C., Zumbrunnen, C., 2008. Integrating humans into ecology: opportunities and challenges for studying urban ecosystems. In: Urban Ecology. Springer, Berlin Heidelberg, pp. 143-158. http://dx.doi.org/10.1177/0160017605275160.

Allen, R.G., Pereira, L.S., Raes, D., Smith, M., 1998. Crop EvapotranspirationGuidelines for Computing Crop Water Requirements-FAO Irrigation and Drainage Paper 56, 300(9). FAO, Rome. D05109.

Barles, S., 2007. A Material Flow Analysis of Paris and its Region. Renewables in a Changing Climate-innovation in the Built Environment, pp. 579-584. http:// halshs.archives-ouvertes.fr/docs/00/17/48/20/PDF/070601-Barles-Cisbat.pdf.

Barles, S., 2009. Urban metabolism of Paris and its region. J. Ind. Ecol. 13 (6), 898-913. http://dx.doi.org/10.1111/j.1530-9290.2009.00169.x.

Baud, I., Grafakos, S., Hordijk, M., Post, J., 2001. Quality of life and alliances in solid waste management: contributions to urban sustainable development. Cities 18 (1), 3-12. http://dx.doi.org/10.1016/S0264-2751(00)00049-4.

Beloin-Saint-Pierre, D., Rugani, B., Lasvaux, S., Mailhac, A., Popovici, E., Sibiude, G., Schiopu, N., 2016. A review of urban metabolism studies to identify key methodological choices for future harmonization and implementation. J. Clean. Prod. http://dx.doi.org/10.1016/j.jclepro.2016.09.014.

Bennett, A.F., Saunders, D.A., 2010. Habitat Fragmentation and Landscape Change. Conservation Biology for All, 93, pp. 1544-1550. Retrieved from: http://www. conbio.org/images/content_publications/Chapter5.pdf.

Bonan, G.B., 2002. Ecological Climatology: Concepts and Applications. Cambridge University Press, Cambridge. http://dx.doi.org/10.1111/j.1442-9993.2010. 02195.x.

Brunner, P.H., 2007. Reshaping urban metabolism. J. Ind. Ecol. 11, 11-13. http:// dx.doi.org/10.1162/jie.2007.1293.

Cadenasso, M.L., Pickett, S.T., Schwarz, K., 2007. Spatial heterogeneity in urban ecosystems: reconceptualizing land cover and a framework for classification. Front. Ecol. Environ. 5 (2), 80-88. http://dx.doi.org/10.1890/1540-9295(2007)5 [80:SHIUER]2.0.CO;2.

Chen, A., Djordjevic, S., Leandro, J., Savic, D., 2010. An analysis of the combined consequences of pluvial and fluvial flooding. Water Sci. Technol. 62 (7), 1491-1498. http://dx.doi.org/10.2166/wst.2010.486.

Chester, M., Pincetl, S., Allenby, B., 2012. Avoiding unintended tradeoffs by integrating life-cycle impact assessment with urban metabolism. Curr. Opin. Environ. Sustain. 4 (4), 451-457. http://dx.doi.org/10.1016/j.cosust.2012.08.004.

Chrysoulakis, N., Lopes, M., San José, R., Grimmond, C.S.B., Jones, M.B., Magliulo, V., González, A., 2013. Sustainable urban metabolism as a link between biophysical sciences and urban planning: the BRIDGE project. Landsc. Urban Plan. 112, 100-117. http://dx.doi.org/10.1016/j.landurbplan.2012.12.005.

Churkina, G., 2008. Modeling the carbon cycle of urban systems. Ecol. Model. 216 (2), 107-113. http://dx.doi.org/10.1016/j.ecolmodel.2008.03.006.

Collins, J.P., Kinzig, A., Grimm, N.B., Fagan, W.F., Hope, D., Wu, J., Borer, E.T., 2000. A New Urban Ecology Modeling human communities as integral parts of ecosystems poses special problems for the development and testing of ecological theory. Am. Sci. 88 (5), 416-425 url: http://www.jstor.org/stable/20440583.

Compton, J.E., Harrison, J.A., Dennis, R.L., Greaver, T.L., Hill, B.H., Jordan, S.J., Campbell, H.V., 2011. Ecosystem services altered by human changes in the nitrogen cycle: a new perspective for US decision making. Ecol. Lett. 14 (8), 804-815. http://dx.doi.org/10.1111/j.1461-0248.2011.01631.x.

Construction Ministry of China, 2002. The Standard of Water Quantity for City's Residential Use (GB/T 50331-2002). China Building Industry Press, Beijing.

Dakhia, K., Berezowska-Azzag, E., 2010. Urban institutional and ecological footprint: a new urban metabolism assessment tool for planning sustainable urbanecosystems. Manag. Environ. Qual. Int. J. 21 (1), 78-89. http://dx.doi.org/ 10.1108/14777831011010874.

Decker, E.H., Elliott, S., Smith, F.A., Blake, D.R., Rowland, F.S., 2000. Energy and material flow through the urban ecosystem. Energy Environ. 25, 685-740. http://dx.doi.org/10.1146/annurev.energy.25.1.685.

Elvidge, C.D., Tuttle, B.T., Sutton, P.C., Baugh, K.E., Howard, A.T., Milesi, C., Nemani, R., 2007. Global distribution and density of constructed impervious surfaces. Sensors 7 (9), 1962-1979. http://dx.doi.org/10.3390/s7091962.

Fu, S.H., Liu, B.Y., Wu, J.D., Duan, S.H., 2002. Study on runoff calculation method in Beijing mountainous area. Dili Kexue Sci. Geogr. Sin. 22 (5), 604-609 (in Chinese).

Godron, M., Forman, R., 1983. Landscape Modification and Changing Ecological Characteristics Disturbance and Ecosystems. Springer, Berlin Heidelberg.

Goldstein, B., Birkved, M., Quitzau, M.B., Hauschild, M., 2013. Quantification of urban metabolism through coupling with the life cycle assessment framework: concept development and case study. Environ. Res. Lett. 8, 035024. http:// dx.doi.org/10.1088/1748-9326/8/3/035024.

Golubiewski, N., 2012. Is there a metabolism of an urban ecosystem? An ecological critique. Ambio 41 (7), 751-764. http://dx.doi.org/10.1007/s13280-011-0232-7.

Grimm, N.B., Faeth, S.H., Golubiewski, N.E., Redman, C.L., Wu, J., Bai, X., Briggs, J.M., 2008. Global change and the ecology of cities. Science 319 (5864), 756-760. http://dx.doi.org/10.1126/science.1150195.

Haes, H.A.U., Heijungs, R., Suh, S., Huppes, G., 2004. Three strategies to overcome the limitations of life-cycle assessment. J. Ind. Ecol. 8 (3), 19-32. http:// dx.doi.org/10.1162/1088198042442351.

Hahs, A.K., McDonnell, M.J., McCarthy, M.A., Vesk, P.A., Corlett, R.T., Norton, B.A., et al., 2009. A global synthesis of plant extinction rates in urban areas. Ecol. Lett. 12 (11), 1165-1173. http://dx.doi.org/10.1111/j.1461-0248.2009.01372.x.

Hau, J.L., Bakshi, B.R., 2004. Promise and problems of emergy analysis. Ecol. Model. 178 (1), 215-225. http://dx.doi.org/10.1016/j.ecolmodel.2003.12.016.

Heaney, J.P., Wright, L., Sample, D., 2000. Sustainable urban water management. In: Field, R., Heaney, J.P., Pitt, R. (Eds.), Innovative Urban Wet-weather Flow Management Systems. Technomic Publishing Company, Pennsylvania, p. 535.

Hendriks, C., Obernosterer, R., Müller, D., Kytzia, S., Baccini, P., Brunner, P.H., 2000. Material flow analysis: a tool to support environmental policy decision making. Case-studies on the city of Vienna and the Swiss lowlands. Local Environ. 5 (3), 311-328. http://dx.doi.org/10.1080/13549830050134257.

Holmes, T., Pincetl, S., 2012. UCLA Institute of the Environment Urban Metabolism Literature Review Winter 2012. http://www.environment.ucla.edu/media/files/ Urban-Metabolism-Literature-Review2012-44-fea.pdf.

Huang, S.L., Chen, C.W., 2009. Urbanization and socioeconomic metabolism in Taipei: an emergy synthesis. J. Ind. Ecol. 13 (1), 75-93. http://dx.doi.org/10.1111/ j.1530-9290.2008.00103.x.

Huang, S.L., Lee, C.L., Chen, C.W., 2006. Socioeconomic metabolism in Taiwan: emergy synthesis versus material flow analysis. Resour. Conserv. Recycl. 48 (2), 166-196. http://dx.doi.org/10.1016/j.resconrec.2006.01.005.

Inostroza, L., 2014. Measuring urban ecosystem functions through 'Technomass'-a novel indicator to assess urban metabolism. Ecol. Indic. 42, 10-19. http:// dx.doi.org/10.1016/j.ecolind.2014.02.035.

Irwin, E.G., Bockstael, N.E., 2007. The evolution of urban sprawl: evidence of spatial heterogeneity and increasing land fragmentation. Proc. Natl. Acad. Sci. 104 (52), 20672-20677. http://dx.doi.org/10.1073/pnas.0705527105.

Kalmykova, Y., Rosado, L., Patrício, J., 2015. Urban economies resource productivity and decoupling: metabolism trends of 1996-2011 in Sweden, Stockholm, and Gothenburg. Environ. Sci. Technol. 49 (14), 8815-8823. http://dx.doi.org/ 10.1021/acs.est.5b01431.

Kalnay, E., Cai, M., 2003. Impact of urbanization and land-use change on climate. Nature 423 (6939), 528-531. 
Kaye, J.P., Groffman, P.M., Grimm, N.B., Baker, L.A., Pouyat, R.V., 2006. A distinct urban biogeochemistry? Trends Ecol. Evol. 21, 192-199. http://dx.doi.org/ 10.1016/j.tree.2005.12.006.

Kennedy, C., Cuddihy, J., Engel-Yan, J., 2007. The changing metabolism of cities. J. Ind. Ecol. 11 (2), 43-59. http://dx.doi.org/10.1162/jie.2007.1107.

Kennedy, C., Steinberger, J., Gasson, B., Hansen, Y., Hillman, T., Havránek, M., Pataki, D., Phdungsilp, A., Ramaswami, A., Mendez, G.V., 2010. Methodology for inventorying greenhouse gas emissions from global cities. Energy Policy 38 (9), 4828-4837. http://dx.doi.org/10.1016/j.enpol.2009.08.050.

Kennedy, C., Pincetl, S., Bunje, P., 2011. The study of urban metabolism and its applications to urban planning and design. Environ. Pollut. 159 (8), 1965-1973. http://dx.doi.org/10.1016/j.envpol.2010.10.022.

Kennedy, C., Stewart, I.D., Ibrahim, N., Facchini, A., Mele, R., 2014. Developing a multi-layered indicator set for urban metabolism studies in megacities. Ecol. Indic. 47, 7-15. http://dx.doi.org/10.1016/j.ecolind.2014.07.039.

Kenny, T., Gray, N.F., 2009. Comparative performance of six carbon footprint models for use in Ireland. Environ. Impact Assess. Rev. 29 (1), 1-6. http://dx.doi.org/ 10.1016/j.eiar.2008.06.001.

Kenway, S., Gregory, A., McMahon, J., 2011. Urban water mass balance analysis. J. Ind. Ecol. 15 (5), 693-706. http://dx.doi.org/10.1111/j.1530-9290.2011.00357.x.

Lee, C.L., Huang, S.L., Chan, S.L., 2009. Synthesis and spatial dynamics of socioeconomic metabolism and land use change of Taipei Metropolitan Region. Ecol. Model. 220 (21), 2940-2959. http://dx.doi.org/10.1016/j.ecolmodel.2009. 06.021.

Lei, K., Liu, L., Hu, D., Lou, I., 2016. Mass, energy, and emergy analysis of the metabolism of Macao. J. Clean. Prod. 114, 160-170. http://dx.doi.org/10.1016/ j.jclepro.2015.05.099.

Lei, X.H., Jiang, Y.Z., Wang, H. (Eds.), 2010. The Distributed Hydrological Model of EasyDHM. China WaterPower Press, Beijing (in Chinese).

Leduc, W.R., Van Kann, F.M., 2013. Spatial planning based on urban energy harvesting toward productive urban regions. J. Clean. Prod. 39, 180-190. http:// dx.doi.org/10.1016/j.jclepro.2012.09.014.

Li, S.S., Zhang, Y., Yang, Z.F., Liu, H., Zhang, J.Y., 2012. Ecological relationship analysis of the urban metabolic system of Beijing, China. Environ. Pollut. 170, 169-176. http://dx.doi.org/10.1016/j.envpol.2012.07.010.

Liu, G.Y., Yang, Z.F., Chen, B., Ulgiati, S., 2011. Monitoring trends of urban development and environmental impact of Beijing, 1999-2006. Sci. Total Environ. 409 (18), 3295-3308. http://dx.doi.org/10.1016/j.scitotenv.2011.05.045.

Lu, Y., Geng, Y., Qian, Y., Han, W., McDowall, W., Bleischwitz, R., 2016. Changes of human time and land use pattern in one mega city's urban metabolism: a multi-scale integrated analysis of Shanghai. J. Clean. Prod. 133, 391-401. http:// dx.doi.org/10.1016/j.jclepro.2016.05.174.

Machlis, G.E., Force, J.E., Burch Jr., W.R., 1997. The human ecosystem part I: the human ecosystem as an organizing concept in ecosystem management. Soc. Nat. Resour. 10 (4), 347-367. http://dx.doi.org/10.1080/08941929709381034.

Marcotullio, P.J., Boyle, G., 2003. Defining an Ecosystem Approach to Urban Management and Policy Development. United Nations University Institute of Advanced Studies, Tokyo.

Marull, J., Pino, J., Tello, E., Cordobilla, M.J., 2010. Social metabolism, landscape change and land-use planning in the Barcelona Metropolitan Region. Land Use Policy 27, 497-510. http://dx.doi.org/10.1016/j.landusepol.2009.07.004.

Minx, J., Creutzig, F., Medinger, V., Ziegler, T., Owen, A., Baiocchi, G., 2011. Developing a pragmatic approach to assess urban metabolism in Europe: a report to the European Environment Agency. In: Climatecon Working Paper Series. Technische Universitat, Berlin.

Mitchell, V.G., McMahon, T.A., Mein, R.G., 2003. Components of the total water balance of an urban catchment. Environ. Manag. 32 (6), 735-746. http:// dx.doi.org/10.1007/s00267-003-2062-2.

Mohurd, A., 2011. Code for Design of Outdoor Wastewater Engineering (GB 500142006). Ministry of Housing and Urban-Rural Development, General Administration of Quality Supervision, Inspection and Quarantine of the People's Republic of China.

Ngo, N., Pataki, D., 2008. The energy and mass balance of Los Angeles County. Urban Ecosyst. 11 (2), 121-139. http://dx.doi.org/10.1007/s11252-008-0051-1.

Novotny, V., 2010. Water and energy footprints for sustainable communities. In: Singapore International Water Week Conference, 20 June-2 July, Singapore.

Pickett, S.T., Cadenasso, M., Grove, J., Nilon, C., Pouyat, R., Zipperer, W., Costanza, R., 2001. Urban ecological systems: linking terrestrial ecological, physical, and socioeconomic components of metropolitan areas. Annu. Rev. Ecol. Syst. 32, 127-157. etal2001.pdf.

Pincetl, S., Bunje, P., Holmes, T., 2012. An expanded urban metabolism method: toward a systems approach for assessing urban energy processes and causes.
Landsc. Urban Plan. 107 (3), 193-202. http://dx.doi.org/10.1016/ j.landurbplan.2012.06.006.

Rees, W.E., 1999. The built environment and the ecosphere: a global perspective. Build. Res. Inf. 27 (4-5), 206-220. http://dx.doi.org/10.1080/096132199369336.

Rosado, L., Niza, S., Ferrão, P., 2014. A material flow accounting case study of the Lisbon metropolitan area using the urban metabolism analyst model. J. Ind. Ecol. 18 (1), 84-101. http://dx.doi.org/10.1111/jiec.12083.

Sahely, H.R., Dudding, S., Kennedy, C.A., 2003. Estimating the urban metabolism of Canadian cities: greater Toronto Area case study. Can. J. Civ. Eng. 30 (2) 468-483. http://dx.doi.org/10.1139/102-105.

Savard, J.P.L., Clergeau, P., Mennechez, G., 2000. Biodiversity concepts and urban ecosystems. Landsc. Urban Plan. 48 (3), 131-142. http://dx.doi.org/10.1016 S0169-2046(00)00037-2.

Su, F., Xie, Z., 2003. A model for assessing effects of climate change on runoff in China. Prog. Nat. Sci. 13 (9), 701-707. http://dx.doi.org/10.1080 10020070312331344270

Sun, L., Dong, H., Geng, Y., Li, Z., Liu, Z., Fujita, T., Fujii, M., 2016. Uncovering driving forces on urban metabolism-A case of Shenyang. J. Clean. Prod. 114, 171-179. http://dx.doi.org/10.1016/j.jclepro.2015.05.053.

Tan, X., Yang J.Z., Song, X.H., Zha, Y.Y., 2013. Estimation of groundwater recharge in North China Plain. Adv. Water Sci. 24 (1), 76-81 (in Chinese).

Tchobanoglous, G., Burton, F.L., Stensel, D.H., 2003. Wastewater Engineering: Treatment Disposal and Reuse, 4th Ed. McGraw-Hill, New York.

Tischendorf, L., 2001. Can landscape indices predict ecological processes consistently? Landsc. Ecol. 16 (3), 235-254. http://dx.doi.org/10.1023/A: 1011112719782

UNFPA, 2007. State of the World Population 2007: Unleashing the Potential Urban Growth. United Nations Population Fund, New York. http://www.unfpa.org/ webdav/site/global/shared/documents/publications/2007/695_filename_ sowp2007_eng.pdf.

Vairavamoorthy, K., Gorantiwar, S.D., Pathirana, A., 2008. Managing urban water supplies in developing countries-Climate change and water scarcity scenarios. Phys. Chem. Earth, Parts A/B/C 33 (5), 330-339. http://dx.doi.org/10.1016/ j.pce 2008.02.008.

Varis, O., Vakkilainen, P., 2001. China's 8 challenges to water resources management in the first quarter of the 21st century. Geomorphology 41 (2), 93-104. http:/ dx.doi.org/10.1016/S0169-555X(01)00107-6.

Vivanco, D.F., Ventosa, I.P., Durany, X.G., 2012. Building waste management core indicators through Spatial Material Flow Analysis: net recovery and transport intensity indexes. Waste Manag. 32 (12), 2496-2510. http://dx.doi.org/10.1016 j.wasman.2012.06.010.

Wang, J., Endreny, T.A., Nowak, D.J., 2008. Mechanistic simulation of tree effects in an urban water balance model1. JAWRA J. Am. Water Resour. Assoc. 44 (1) 75-85. http://dx.doi.org/10.1111/j.1752-1688.2007.00139.x.

Warren-Rhodes, K., Koenig, A., 2001. Escalating trends in the urban metabolism of Hong Kong: 1971-1997. AMBIO: A J. Hum. Environ. 30 (7), 429-438. http:// dx.doi.org/10.1579/0044-7447-30.7.429.

Wolman, A., 1965. The metabolism of cities. Sci. Am. 213, 178-190, http:/ dx.doi.org/10.1038/scientificamerican0965-178.

Xie, Y., Huang, G., Zhao, L., 1998. Spatial variability of field soil properties. J. China Agric. Univ. 3 (2), 41-45 (in Chinese).

Xu, X., 1998. Simulation of storm runoff process for plain urban. Shuili Xuebao J. Hydraul. Eng. 8 (8), 34-37 (in Chinese).

Yang, D., Kao, W.T.M., Zhang, G., Zhang, N., 2014. Evaluating spatiotemporal differences and sustainability of Xiamen urban metabolism using emergy synthesis. Ecol. Model. 272, 40-48. http://dx.doi.org/10.1016/j.ecolmodel. 2013.09.014.

Zhang, X., Hu, M., Chen, G., Xu, Y., 2012. Urban rainwater utilization and its role in mitigating urban waterlogging problems-a case study in Nanjing, China. Water Resour. Manag. 26 (13), 3757-3766. http://dx.doi.org/10.1007/s11269-012 0101-6.

Zhang, Y., Yang, Z.F., Li, W., 2006. Analyses of urban ecosystem based on information entropy. Ecol. Model. 197 (1-2), 1-12. http://dx.doi.org/10.1016/j.ecolmodel. 2006.02.032.

Zhang, Y., Yang, Z.F., Yu, X.Y., 2009. Evaluation of urban metabolism based on emergy synthesis: a case study for Beijing (China). Ecol. Model. 220 (13-14) 1690-1696. http://dx.doi.org/10.1016/j.ecolmodel.2009.04.002.

Zhang, Y., Yang, Z.F., Fath, B.D., Li, S.S., 2010. Ecological network analysis of an urban energy metabolic system: model development, and a case study of four Chinese cities. Ecol. Model. 221 (16), 1865-1879. http://dx.doi.org/10.1016/j.ecolmodel. 2010.05.006.

Zhang Y, 2013. Urban metabolism: a review of research methodologies. Environ. Pollut. 178, 463-473. http://dx.doi.org/10.1016/j.envpol.2013.03.052. 